\title{
Phospholipases in Bacterial Virulence and Pathogenesis
}

\author{
Kumari Bandana, Kaur Jashandeep and Kaur Jagdeep* \\ Department of Biotechnology, Panjab University, India
}

Submission: June14, 2018; Published: September 04, 2018

*Corresponding author: Jagdeep Kaur, Professor, Department of Biotechnology, BMS Block-1, South Campus, Panjab University, Chandigarh 160014, India, Tel: (o)0172-2534085, Fax: + 91-172-2541409; Email; jagsekhon@pu.ac.in

\begin{abstract}
Phospholipases are ubiquitous hydrolases that catalyze the hydrolysis of phospholipids, a key component of eukaryotic cellular membranes. The metabolites generated after hydrolysis functions as secondary messengers that are further involved in signal transduction, membrane trafficking, cell proliferation, etc. These enzymes are considered as an important virulence factors, as they help the bacterial pathogens in number of ways like host cell invasion, modulating the phospholipid content of their membrane, and so on. Also, these enzymes are crucial for the pathogenesis of certain bacteria because of their role in escape from the host defence mechanism. This review is focused on different diversity of PLs and their role in pathogenesis and virulence in bacterial infection.
\end{abstract}

Keywords: Phospholipase; Virulence; Pathogenesis; Host cell invasion; Lipid droplet; Phosphatidylcholine; Drug target

Abbreviations: PLA: Phospholipase A; PLB: Phospholipases B; PLD: Phospholipase D; SAM: Sterile Alfa Motif; SG: Src Homology; PMN: Polymorphonuclear Cells

\section{Introduction}

Infectious diseases are caused by bacteria, fungi, viruses, or parasites. These may be communicable, acquired from contaminated food or water, or may spread by insect bites, etc. A number of bacteria reside inside the human host harmlessly and some of them are even beneficial, but there are some bacteria that are responsible for causing disease under certain conditions. Few of the bacterial infections are deadliest like tuberculosis [1], acinetobacter infections, memingitis, salmonellosis, etc which claim lives of a number of people every year. Antibiotics are used as the medication for their treatment as they interfere in the processes that are crucial for bacterial survival. But in due course of time, bacteria become resistant to these antibiotics and it becomes difficult to control these infectious diseases [2]. So, by having the complete knowledge of the whole process of bacterial infections and various virulence factors that are responsible for their pathogenesis, it would be easier to combat the disease. These microbial pathogens invade the host defense mechanism by using a number of genetic strategies [3]. The bacteria use multiple virulence factors that enable the bacteria to replicate, colonize, and disseminate within the host. In the process of bacterial pathogenesis, the bacteria have to invade the host cell which can involve enzymes and toxins [4]. Phospholipases (PLs) are reported to be one of the enzymes involved in host cell invasion in a number of diseases [5].

\section{Phospholipids and phospholipases}

Phospholipids are the key component of cellular membrane that provides the binding site for both cellular and extracellular proteins. They are derivatives of glycerol-3-phosphate that is esterified at its carbon (sn-1 or sn-2) positions to non-polar fatty acids and at its phosphoryl group to a polar head group composed of nitrogenous base, inositol unit or glycerol [6]. Metabolites such as arachidonic acid (ARA), diglycerol that are generated after the catalysis of phospholipids by PLs can function as lipid mediators or second messengers that are involved in the membrane trafficking, cell proliferation, signal transductiona and apoptotic cell injury [7]. PLs are a ubiquitous group of hydrolases which are involved in the family of lipolytic enzymes that catalyze the hydrolysis of phospholipids into fatty acids and other lipophilic substances.

Phospholipases (PLs) are a heterogeneous group of enzymes which cleaves the ester bonds of phospholipids. They are mainly associated with the cell membranes and membranebond vesicles and are responsible for the destabilization of membranes and cell signaling [8,9]. The product release by the hydrolysis of phospholipids by PLs has been reported to play an important role in host cell penetration and cell lysis. Moreover, they are active component of bacterial toxins and also found in arthropod poisons and snake venoms [8]. The various functions 
of PLs range from catalysis of nutrients to the formation of bioactive molecules. PLs are critical to life because of their diverse functions [10]. They have been implicated as virulence and pathogenic factors in many pathogenic microorganisms [1113]. Consequently, PLs of many pathogenic bacteria have also been associated with cell death and exhibits cytotoxic effects on human macrophages $[14,15]$.

The PLs are diverse in the site of action on phospholipids molecules and therefore they are classified into 4 types namely A, B, C and D (Figure 1) (Table 1). Phospholipase A (PLA) is further classified into two subtypes A1 that cleave the acyl ester bond at sn- 1 position and A2 cleaves at sn- 2 position. On the bases of cellular localization the isozymes of PLA1 is divided

Table 1: Types and properties of phospholipases. into two groups i.e. intracellular and extracellular enzymes (Figure 2) [16]. Similarly, PLA2 has been sorted into 5 main types that further contain different groups (group I-XV) (Figure 3) [17]. Some PLs hydrolyze both acyl groups and are termed the phospholipases B (PLB), also known as lysophospholiapse [18]. Enzymes grouped under phospholipase C (PLC) cleaves glycerophosphate bond on the glycerol side, while phospholipase $\mathrm{D}$ (PLD) catalyses the removal of base group on the polar side of phospholiapse $[19,20]$. The PLC and PLD are therefore also known as phosphodiesterases. Till now, 13 PLC isoenzymes have been identified that are grouped into six different subfamilies (Figure 4) [20]. There are two isoforms of PLD (Figure 5). In addition to bacteria, PLD has been reported in many plants, viruses, worms, flies and yeast [21].

\begin{tabular}{|c|c|c|c|c|c|}
\hline S.No & Types & Subtype & EC number & $\begin{array}{l}\text { Cleavage site in } \\
\text { phospholipids }\end{array}$ & Product \\
\hline 1 & \multirow{2}{*}{$\begin{array}{c}\text { Phospholipase A } \\
\text { (PLA) }\end{array}$} & PLA1 & 3.1.1.32 & SN-1 acyl chain & $\begin{array}{l}\text { Fatty acid and } \\
\text { lysophospholipd }\end{array}$ \\
\hline 2 & & PLA2 & 3.1.1.4 & SN-2 acyl chain & $\begin{array}{l}\text { Arachidonic acid and } \\
\text { lysophosphatidic acid }\end{array}$ \\
\hline 3 & $\begin{array}{l}\text { Phospholipase B } \\
\text { (PLB) }\end{array}$ & & & $\begin{array}{l}\text { Both } \mathrm{SN}-1 \text { and } \mathrm{SN}-2 \\
\text { acyl chain }\end{array}$ & \\
\hline 4 & $\begin{array}{l}\text { Phospholipase C } \\
\text { (PLC) }\end{array}$ & & EC 3.1.4.3 & Before phosphate & $\begin{array}{c}\text { Diacylglycerol and a } \\
\text { phosphate-containing } \\
\text { head group }\end{array}$ \\
\hline 5 & $\begin{array}{l}\text { Phospholipase D } \\
\text { (PLD) }\end{array}$ & & EC 3.1.4.4 & After Phosphate & $\begin{array}{l}\text { Phosphatidic acid and } \\
\text { an alcohol }\end{array}$ \\
\hline
\end{tabular}

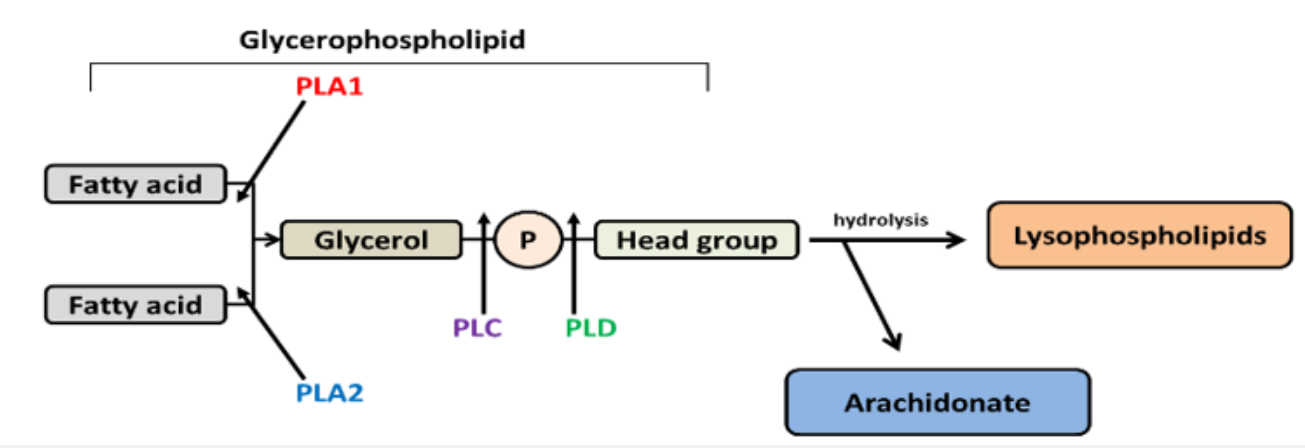

Figure 1: Site of action of different phospholipases in phospholipid molecule.

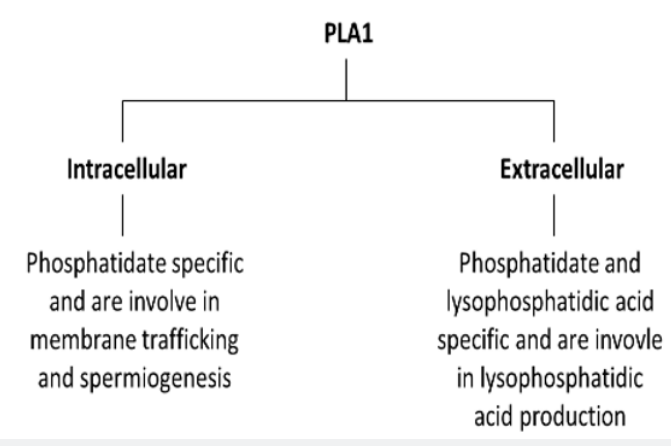

Figure 2: Isoforms of PLA1 and their function. 


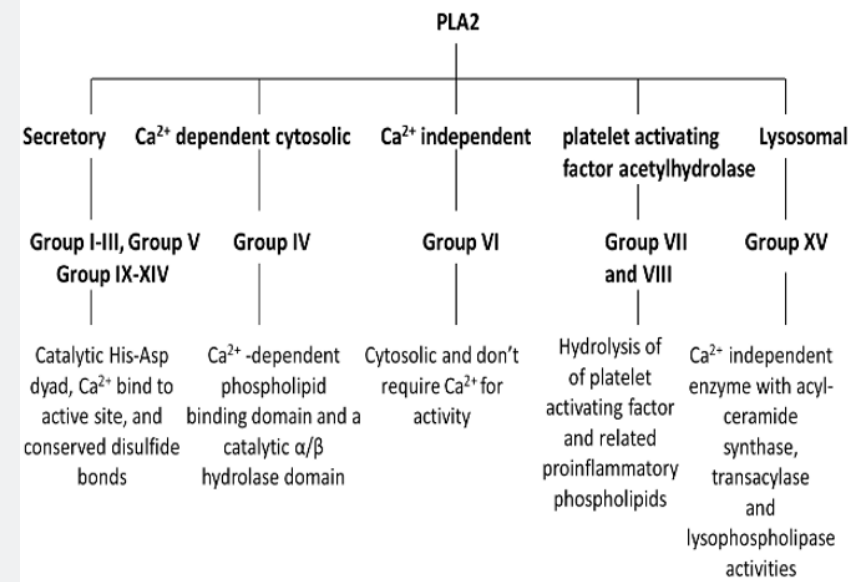

Figure 3: Types of PLA2 and their role.

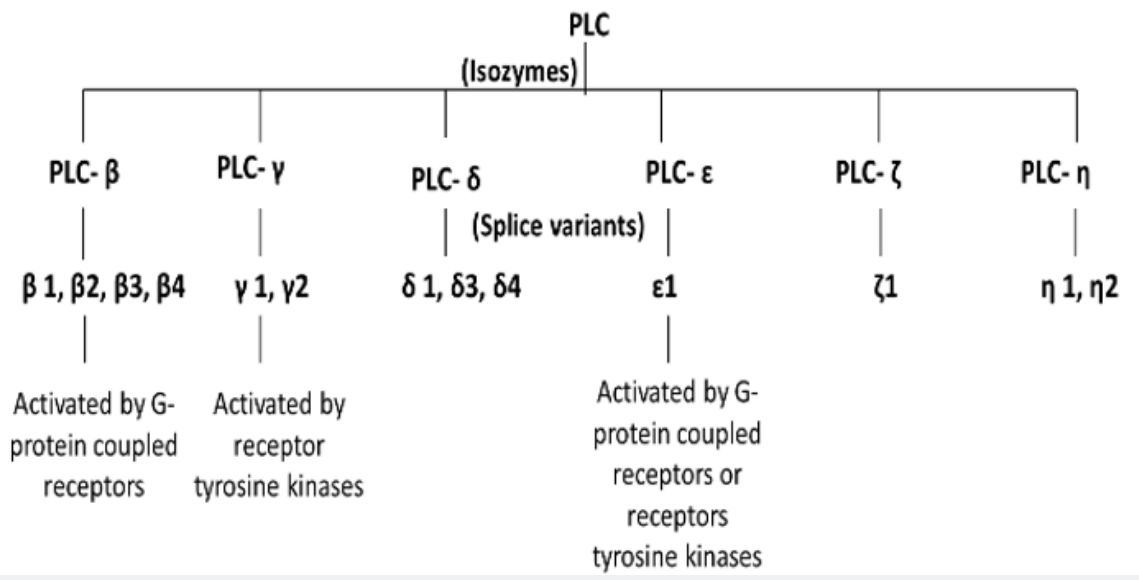

Figure 4: Isozymes and different splicing variants of PLC.

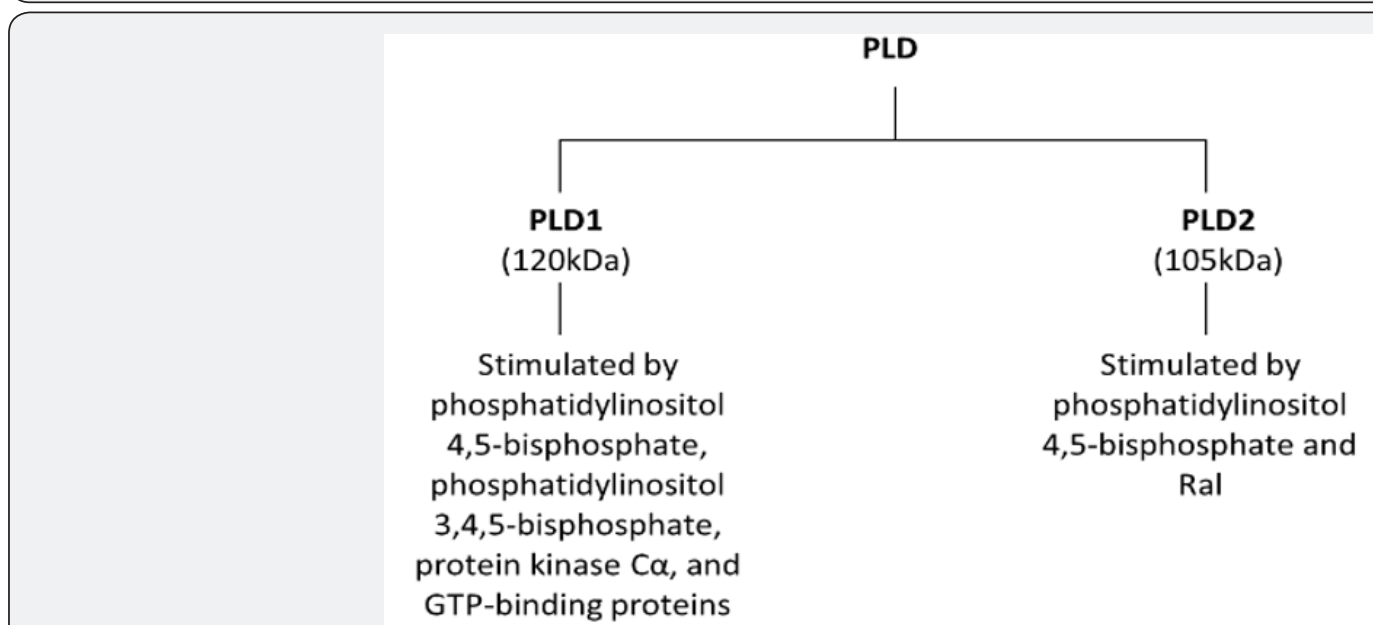

Figure 5: Isoforms of mammalian PLD.

\section{Structural analysis}

It is very important to understand the three dimensional structure of enzyme to examine its significant role in the pathophysiology of the microorganisms in disease. PLA1 contains the lipase consensus sequence (Gly-x-Ser-x-Gly), a catalytic triad (Ser-Asp-His) with serine at its active site and shares a multiple conserved motifs. Intracellular PLA1 mainly contains DDHD domain and some of them have a sterile alfa motif (SAM) which is important for the binding of enzyme to the intracellular membrane [22]. Extracellular PLA1 contains surface loops known as lids, $\beta 5$ loops and $\beta 9$ loops. Subfamilies present in secretary PLA1 mainly varies due to the length of lids 
and $\beta 9$ loops. Notably, PLA1 that posses triacylglycerol hydrolase activity generally have long lids (22-23 amino acids) and long $\beta 9$ loops (18-19 amino acids), whereas PLA1- $\alpha$ and PLA1- $\beta$ that do not exhibits triacylglycerol hydrolase activity contain short lids (7-12 amino acids) and $\beta 9$ loops (12-13 amino acids) [23].

PLA2 belongs to the $\alpha / \beta$ hydrolse family. $\beta$ - sheets are generally present in the enzyme core whose strands are interconnected by $\alpha$-helices and catalytic serine is present in tight turn between $\alpha / \beta$ strand. Secreted PLA2 contains His-Asp catalytic diad and a Ca2+ binding site, whereas cytosolic PLA2 contains $\mathrm{Ca} 2+$ dependent phospholipid domain and its active site is covered by the cap region [24]. Plasma platelet activating factor-acetylhydrolase and Lysosomal PLA2 contains lipase motif (Gly-x-Ser-x-Gly), the catalytic Ser-Asp-His triad, and serine active site. They also contains the $\mathrm{N}$-glycolation site and an $\mathrm{N}$-terminal signal sequence [25].

PLC contains X and Y catalytic domain that comprise highly conserved amino acid regions in isozymes. They are located between EF-hand motif which is a helix-turn-helix structural domain that binds $\mathrm{Ca} 2+$ ions and $\mathrm{C} 2$ domain that also contains three to four $\mathrm{Ca} 2+$ binding sites and regulates the enzyme activity. It has been shown that plekstrin homology $(\mathrm{PH})$ domain is located in the $\mathrm{N}$ - terminal region and it provides the passage onto the membrane surface [20]. PLC- $\beta$ and PLC- $\gamma$ contains an additional $\mathrm{COOH}$ - terminal and $\mathrm{SH}$ domain respectively that is responsible for the membrane attachment and in mitogenic signaling [20]. PLD contains the sequence motif HXK(X)4D, which is found twice without exception in all known isoforms of enzyme and denoted as HKD motif [21]. This motif has been involved in signal transduction and lipid biosynthesis in many pathogenic bacteria [26]. Phox consensus sequence (PX), the $(\mathrm{PH})$ domain is the other highly conserved regions which are involved in lipid binding [27].

\section{Mechanism of action}

The PLA gene family member shares a multiple conserved motif that includes G-X-S-X-G motif, a catalytic triad and cysteine residues that moderated disulphide bond formation. It contains the $\mathrm{N}$-terminal signal sequence followed by catalytic triad with
Ser154, Asp178, and His249. Glycosylation is critical for the catalytic activity and four acceptors sequences of $\mathrm{N}$-glycosylation sites are present at amino acid 50, 58, 66 and 357 positions [28]. The catalytic action of PLA2 proceeds through the Serine-acyl intermediate that is present in a pentapeptise sequence G-L-LG-S using serine-228 as nuclephilic residue. This catalytic serine residue is termed as "nucleophilic elbow". It has been reported that in addition to Serine-288, Asp-549 and Arg-200 is also found to be essential for the activity [24].

The X and Y structural domain of PLC are responsible for the catalytic activity of the enzyme. Based on the structural analysis it has been reported that Lysine-438, Lysine-440, Serine-522 and Arginine-549 are present at active site which are implicated in the binding with the phosphate group [20]. PH domain moderates the binding of enzyme to phospholipids. PLC- $\gamma$ contains the long amino acid sequence that contain Src homology (SG) domain which mediated the interaction with other proteins [29]. Phospholipase D crystal structure reveals that it contain two motif from single active site and the histidine residue from one motif acts as a nucleophile in the catalytic mechanism of the enzyme forming an intermediate of phosphoenzyme whereas, the histidine residue of second motif cleaves the phosphodiester bond [26]. PH and PX domain also plays an important role in the catalysis of enzyme. PH domain helps in the localization of the protein whereas; PX domain is thought to mediate the protein- protein interaction. The lysine residue conserved in the structure is involved in phosphate binding [27].

Role in virulence and pathogenesis: Several bacteria and fungi produce extracellular phospholipases, which helps them to invade the host by damaging its cell membrane $[8,30,31]$. The presence of their activity is generally associated to the virulence of the pathogen. The strains of Candida albicans with highest phospholipase activity showed the greatest mortality in mice [8]. Also, only phospholipase activity was predictive of mortality among a number of candidate factors in C. albicans [32]. It has been reported that Aspergillus fumigatus was able to produce different type of phospholipases like PLA, PLB, PLC, and PLD [33]. Different phospholipases that play an important role in bacterial virulence and pathogenesis are mentioned in Table 2.

Table 2: Different bacteria possessing different type of phospholipases.

\begin{tabular}{|c|c|c|c|}
\hline Organism & Phospholipase type & Function of enzyme & References \\
\hline Pseudomonas aeruginosa & PLC & Colonization of tissues & {$[45]$} \\
\hline C. perfringens & PLC (alpha toxin) & Host tissue invasion & {$[34]$} \\
\hline Clostridium novyi & PLC (gamma toxin) & Hemolytic activity & {$[36]$} \\
\hline L. monocytogenes & PLC & $\begin{array}{c}\text { Bacterial escape from } \\
\text { phagosomes }\end{array}$ & {$[47]$} \\
\hline Pseudomonas cepacia & PLC & Hemolytic activity & {$[48,49]$} \\
\hline Staphylococcus aureus & PLC (beta toxin) & Hemolytic activity & {$[50]$} \\
\hline Bacillus cereus & PLC & Protects against phagocytosis & Role in virulence and \\
pathogenesis & {$[38,51,52]$} \\
\hline M. tuberculosis & PLD, PLA, PLC & Host cell invasion & {$[53,54]$} \\
\hline Rickettsia prowazekii & PLA &
\end{tabular}


Advances in Biotechnology \& Microbiology

\begin{tabular}{|c|c|c|c|}
\hline Arcanobacterium haemolyticum & PLD & Virulence determinant & {$[55]$} \\
\hline Cryptococcus neoformans & PLB & $\begin{array}{l}\text { Necessary for central nervous } \\
\text { system infection }\end{array}$ & {$[56]$} \\
\hline Yersinia enterocolitica & PLA2 & Promoting colonization & [57] \\
\hline Campylobacter coli & PLA & Haemolytic activity & [58] \\
\hline Yersinia pseudotuberculosis & PLA & Host cell invasion & [59] \\
\hline Helicobacter pylori & PLA1 & $\begin{array}{l}\text { Host cell membrane disruption } \\
\text { during invasion }\end{array}$ & [60] \\
\hline Campylobacter jejuni & PLA & Promoting colonization & [61] \\
\hline Legionella pneumophila & PLA & $\begin{array}{l}\text { Bacterial detoxification of } \\
\text { lysophospholipids }\end{array}$ & [62] \\
\hline Legionella pneumophila & PLB, PLC, PLD & virulence & {$[63,64]$} \\
\hline Campylobacter concisus & Membrane bound PLA & Haemolytic activity & {$[65]$} \\
\hline $\begin{array}{l}\text { Neisseria meningitides, } N . \\
\text { gonorrhoeae }\end{array}$ & Outer membrane associated PL & Autolysin & [66] \\
\hline A. baumannii & PLD & Virulence and Host cell invasion & [36] \\
\hline Plasmodium falciparum & PLA2 & Brain swelling & [67] \\
\hline B. melitensis & PLA1 & $\begin{array}{l}\text { Polymyxin resistance and } \\
\text { pathogenicity }\end{array}$ & [35] \\
\hline S. pneumoniae & PLA2 & Pulmonary inflammation & [39] \\
\hline Vibrio vulnificus & PLA2 & $\begin{array}{l}\text { Lysis and necrotic death of } \\
\text { epithelial cells }\end{array}$ & [68] \\
\hline
\end{tabular}

Phospholipases are important virulence factors as they are able to cleave phospholipids in eukaryotic membranes and the products might act as signaling molecules, which ultimately leads to a number of events to occur favorable for the pathogen [14]. They help the bacterial pathogens to invade the host cells by destroying the phospholipids of cell membranes. The role of $\alpha$-toxin (PLC) was confirmed when $\alpha$-toxin mutant from a virulent strain of Clostridium perfringens was unable to cause tissue damage and necrosis in mice hind limbs after inoculation [34]. Also, they modulates phospholipid content of cell envelope of certain bacteria, which would be helpful for the pathogenesis of bacteria like PLA1 of Brucella melitensis is responsible for the resistance against polymyxin $\mathrm{B}$ and also contributed to host-pathogen interactions [35]. There are three PLDs in Acinetobacter baumannii and are major virulence factors as they are required for host cell invasion. All three PLDs were necessary for the full invasion and virulence as they work in concerted manner, confirmed when the inactivation of all three pld genes leads to the minimum invasion efficiency [36]. Moreover, they play an important role in pathogenesis of intracellular pathogens as they help the bacteria to escape from phagosomes in certain cases. Two PLC were found in Listeria monocytogenes which aid the bacterial escape from phagosomes as this was confirmed by creating its mutants. The individual mutants of plcA or plcB were two and 20 fold, respectively, less virulent, but a double mutant was 500 -fold less virulent in mice deciphering the significance of this enzyme for the virulence and pathogenesis of the bacteria [37].

The intracellular lung pathogen, Mycobacterium tuberculosis also possessed phospholipases which are important for its virulence and pathogenesis too. There are four genes (plcA,
plcB, plcC, plcD) that encode PLC enzyme. Mutation studies demonstrated that all four genes were required to encode a functional PLC. The expression of these genes was upregulated during first $24 \mathrm{hr}$ of infection suggesting the role of PLC in the virulence of the bacteria [38].

Sometimes, they are very crucial to the pathogens that without them bacteria would be unable to survive in the host. One such example is the PLA2 enzyme of Streptococcus pneumoniae which elicits pulmonary inflammation during infection and is also required for lethal systemic infection [39]. PLA2 enzyme inhibitors almost blocked (diminished by $>80 \%$ ) the polymorphonuclear cells (PMN) transepithelial migration in vitro [40]. Also, PLA2-deficient mice were survived from S. pneumoniae bacteremia challenge which was otherwise lethal to wild-type mice [41]. The byproducts of this enzyme catalysis lead to the formation of certain metabolites that aid in the inflammatory processes and in that case phospholipase inhibition could be a more effective anti-inflammatory approach [42]. Like bacteria, snake venom is enormously rich in these enzymes and their inhibitors could prevent skeltel muscle necrosis and permanent injuries in snakebite victims [43].

They also play anabolic roles. There are two PLA2 that are pivotal in lipid droplet formation in case of Hepatitis $\mathrm{C}$ virus infection (HCV). Their knockdown studies showed that their function were irreplaceable and could not be restored even on complementation with each other and lipid droplet formation activity was also found to be impaired. These two PLA2 were found to be play an important role in HCV replication and pathogenesis and they could be a target for an anti-HCV drug [44-68]. 


\section{Conclusion}

Phospholipids are key components of cell membrane of all eukaryotes. The pathogens vary in their preference for the usage of carbon sources during host colonization like mucus sugars, amino acids, lactic acid and many more [69]. In human host, phospholipids are abundant as they are the major building blocks of biological membranes. So, they serve as good candidate for carbon and energy source for the pathogens. Among them, phosphatidylcholine accounts for $50 \%$ of all phospholipids and its prevalence is upto $80 \%$ in the lungs [70,71]. During lung infections by pathogens like A. baumannii, P. aeruginosa, M. tuberculosis; phosphatidylcholine serve as nutrient source $[72,73]$. The pathogens must possess certain enzymes for the utilization of these phospholipids and phospholipases are such enzymes. The role of phospholipases in the virulence and pathogenesis of the disease is equally diverse as they are a diverse group of enzymes. These enzymes are involved in various processes like host cell membrane disruption [10], promote colonization [57], detoxification of toxic lipids [62], cell signaling, etc. They also help bacteria in various ways to cause disease in host and in some infections, these are the key enzymes. So, phospholipases could be used as probable drug targets to combat different bacterial infections.

The different approaches may include the development of vaccines, identification of various enzyme inhibitors, and identification of agents that inhibit the production of enzyme. In today's world, high throughput screening of small molecular inhibitors could also be possible in very short time [74]. As phospholipases are critical to some bacterial pathogens, their inhibition by various inhibitors could lead to the diminished virulence and they could be used as probable drug targets to combat the bacterial infections in future.

\section{Acknowledgement}

Authors dully acknowledge CSIR for providing fellowship to Bandana Kumari and Jashandeep Kaur; and ICMR, India for the financial support provided to Prof. Jagdeep Kaur.

\section{References}

1. Kaur G, Saini V, Kumari B, Kaur J, Kaur J (2017) Characterization of an extracellular protein, Rv1076 from M. tuberculosis with a potential role in humoral response. Int J Biol Macromol 101: 621-629.

2. Piotrowska M, Rzeczycka M, Ostrowski R, Popowska M (2017) Diversity of Antibiotic Resistance Among Bacteria Isolated from Sediments and Water of Carp Farms Located in a Polish Nature Reserve. Polish Journal of Environmental Studies 26(1):239-259.

3. Ribet D, Cossart P (2015) How bacterial pathogens colonize their hosts and invade deeper tissues.

Microbes Infect17(3): 173-183.

4. Songer JG (1997) Bacterial phospholipases and their role in virulence. Trends Microbiol 5(4): 156-161.

5. Schmiel DH, Miller VL (1999) Bacterial phospholipases and pathogenesis. Microbes Infect1(13): 1103-1112.
6. Dennis EA (2015) Introduction to thematic review series: phospholipases: central role in lipid signaling and disease. J Lipid Res 56(7): 1245-1247.

7. Hiroyasu Sato, Yoshitaka Taketomi, and Makoto Murakami (2016) Metabolic regulation by secreted phospholipase A 2. Inflamm Regen. 36(1) :7.

8. Barrett-Bee K, Hayes Y, Wilson RG, Ryley JF (1985) A comparison of phospholipase activity, cellular adherence and pathogenicity of yeasts. J Gen Microbiol 131(5): 1217-1221.

9. Cox GM, McDade HC, Chen SC, Tucker SC, Gottfredsson M, et al. (2001) Extracellular phospholipase activity is a virulence factor for Cryptococcus neoformans. Mol Microbiol 39(1): 166-175.

10. Istivan TS, Coloe PJ (2006) Phospholipase A in Gram-negative bacteria and its role in pathogenesis. Microbiology 152(5): 1263-1274.

11. Pini G, Faggi E, Campisi E (2017) Enzymatic characterization of clinical and environmental Cryptococcus neoformans strains isolated Rev Iberoam Micol 34(2): 77-82.

12. Watkins RA, King JS, Johnston SA (2017) Nutritional Requirements and Their Importance for Virulence of Pathogenic Cryptococcus Species. Microorganisms 5(4): 65.

13. Larkin E, Hager C, Chandra J, Mukherjee PK, Retuerto M, et al. (2017) The emerging Candida auris: characterization of growth phenotype, virulence factors, antifungal activity, and effect of SCY-078, a novel glucan synthesis inhibitor, on growth morphology and biofilm formation. Antimicrobial Agents and Chemother 61(5): 02396-16.

14. Flores-Díaz M, Monturiol-Gross L, Naylor C, Alape-Girón A, Flieger A (2016) Bacterial sphingomyelinases and phospholipases as virulence factors. Microbiol Mol Biol Rev 80(3): 597-628.

15. Brown RE, Hunter RL, Hwang SA (2017) Morphoproteomic-Guided Host-Directed Therapy for Tuberculosis. Front Immunol 8: 78.

16. Scandella CJ, Kornberg A (1971) Membrane-bound phospholipase A1 purified from Escherichia coli. Biochemistry 10(24): 4447-4456.

17. Vasquez AM, Mouchlis VD, Dennis EA (2017) Review of four major distinct types of human phospholipase $\mathrm{A}_{2}$. Adv Biol Regul 67: 212-218.

18. Leidich SD, Ibrahim AS, Fu Y, Koul A, Jessup C, et al. (1998) Cloning and disruption of caPLB1, a phospholipase B gene involved in the pathogenicity of Candida albicans. J Biol Chem 273(40): 26078-26086.

19. Abdulnour RE, Howrylak JA, Tavares AH, Douda DN, Henkels KM (2016) Phospholipase D isoforms differentially regulate leukocyte responses to acute lung injury. J Leukoc Biol 103(5): 919-932.

20. Suh PG1, Park JI, Manzoli L, Cocco L, Peak JC, et al. (2008) Multiple roles of phosphoinositide-specific phospholipase $\mathrm{C}$ isozymes. BMB Rep 41(6): 415-34.

21. Frohman MA, Sung TC, Morris AJ (1999) Mammalian phospholipase D structure and regulation. Biochim Biophys Acta 1439(2): 175-186.

22. Tani K, Baba T, Inoue H (2014) The Structures and Functions of Intracellular Phospholipase A1 Family Proteins, Phospholipases in Health and Disease. Springer, Pp. 87-99.

23. Aoki J, Inoue A, Makide K, Saiki N, Arai H (2007) Structure and function of extracellular phospholipase A 1 belonging to the pancreatic lipase gene family. Biochimie 89(2): 197-204.

24. Wang H, Klein MG, Snell G, Lane W, Zou H, et al. (2016) Structure of Human GIVD Cytosolic Phospholipase A 2 Reveals Insights into Substrate Recognition. J Mol Biol 428(13): 2769-2779.

25. Dessen A, Tang J, Schmidt H, Stahl M, Clark JD, et al. (1999) Crystal structure of human cytosolic phospholipase A 2 reveals a novel topology and catalytic mechanism. Cell 97(3): 349-360. 


\section{Advances in Biotechnology \& Microbiology}

26. Stuckey JA, Dixon JE (1999) Crystal structure of a phospholipase D family member. Nat Struct Biol 6(3): 278-84.

27. Jenkins GM, Frohman MA (2005) Phospholipase D: a lipid centric review. Cell Mol Life Sci 62(19-20): 2305-2316.

28. Inoue A, Aoki J(2006) Phospholipase A1: structure, distribution and function. Future Lipidology 6: 687-700.

29. Rhee SG, Bae YS (1997) Regulation of phosphoinositide-specific phospholipase C isozymes. J Biol Chem 272(24): 15045-15048.

30. Meyers DJ, Palmer KC, Bale LA, Kernacki K, Preston M, et al. (1992) In vivo and in vitro toxicity of phospholipase $\mathrm{C}$ from Pseudomonas aeruginosa. Toxicon 30(2): 161-169.

31. Wilson BA, Salyers AA, Whitt DD, Winkler ME (2011) Bacterial pathogenesis: a molecular approach, American Society for Microbiology (ASM).

32. Ibrahim AS1, Mirbod F, Filler SG, Banno Y, Cole GT, et al. (1995) Evidence implicating phospholipase as a virulence factor of Candida albicans. Infect Immun 63(5): 1993-1998.

33. Birch M, Robson G, Law D, Denning DW (1996) Evidence of multiple extracellular phospholipase activities of Aspergillus fumigatus. Infect Immun 64(3): 751-755.

34. Awad MM, Bryant AE, Stevens DL, Rood JI (1995) Virulence studies on chromosomal $\alpha$-toxin and $\Theta$-toxin mutants constructed by allelic exchange provide genetic evidence for the essential role of $\alpha$-toxin in Clostridium perfringens-mediated gas gangrene. Mol Microbiol 15(2): 191-202.

35. Kerrinnes T, Young BM, Leon C, Roux CM, Tran L, et al. (2015) Phospholipase A1 modulates the cell envelope phospholipid content of Brucella melitensis, contributing to polymyxin resistance and pathogenicity. Antimicrob Agents Chemother 59(11): 6717-6724.

36. Stahl J, Bergmann H, Göttig S, Ebersberger I, Averhoff B (2015) Acinetobacter baumannii virulence is mediated by the concerted action of three phospholipases D. PloS one 10(9): e0138360.

37. Smith GA, Marquis H, Jones S, Johnston NC, Portnoy DA, et al. (1995) The two distinct phospholipases $\mathrm{C}$ of Listeria monocytogenes have overlapping roles in escape from a vacuole and cell-to-cell spread. Infect Immun 63(11): 4231-4237.

38. Raynaud C, Guilhot C, Rauzier J, Bordat Y, Pelicic V, et al. (2002) Phospholipases $\mathrm{C}$ are involved in the virulence of Mycobacterium tuberculosis. Mol Microbiol 45(1): 203-217.

39. R Bhowmick R, Clark S, Bonventre JV, Leong JM, McCormick BA (2017) Cytosolic phospholipase A2 $\alpha$ promotes pulmonary inflammation and systemic disease during Streptococcus pneumoniae infection. Infect Immun 85(11): e00280-17.

40. Bonventre JV(1999) The 85-kD Cytosolic Phospholipase A2 Knockout Mouse A New Tool for Physiology and Cell Biology. J Am Soc Nephrol 10(2): 404-412.

41. Bhowmick R, Maung N, Hurley BP, Ghanem EB, Gronert K, et al. (2013) Systemic Disease during Streptococcus pneumoniae Acute Lung Infection Requires 12-Lipoxygenase-Dependent Inflammation. J Immunol 191(10): 5115-5123.

42. Meyer MC, Rastogi P, Beckett CS, McHowat J (2005) Phospholipase A2 inhibitors as potential anti-inflammatory agents. Curr Pharm Des 11(10): 1301-1312.

43. Fernandes CA, Cardoso FF, Cavalcante WG, Soares AM, Dal-Pai M, et al. (2015) Structural basis for the inhibition of a phospholipase A2-like toxin by caffeic and aristolochic acids. PloS one 10(7): e0133370.

44. Su X, Liu S, Zhang X, Lam SM, Hu X, et al. (2017) Requirement of cytosolic phospholipase A2 gamma in lipid droplet formation. Biochim Biophys Acta 1862(7): 692-705.
45. Granström M, Ericsson A, Strandvik B, Wretlind B, Pavlovskis OR et al. (1984) Relation between antibody response to Pseudomonas aeruginosa exoproteins and colonization/infection in patients with cystic fibrosis. Acta Paediatrica 73(6): 772-777.

46. Taguchi R, Ikezawa H (1975) Phospholipase C from Clostridium novyi type A. I. Biochim Biophys Acta 409(1): 75-85.

47. Vasil M, Krieg D, Kuhns J, Ogle J, Shortridge V, et al. (1990) Molecular analysis of hemolytic and phospholipase $\mathrm{C}$ activities of Pseudomonas cepacia. Infection and Immunity 58(12): 4020-4029.

48. Rogolsky M (1979) Nonenteric toxins of Staphylococcus aureus. Microbiol Rev 43(3): 320-360.1

49. Doery HM, Magnusson BJ, Gulasekharam J, Pearson JE (1965) The properties of phospholipase enzymes in staphylococcal toxins. J Gen Microbiol 40(2): 283-296.

50. Kuppe A, Evans LM, McMillen DA, Griffith OH (1989) Phosphatidylinositol-specific phospholipase $\mathrm{C}$ of Bacillus cereus: cloning, sequencing, and relationship to other phospholipases. J Bacteriol 171(11): 6077-6083.

51. Johansen KA, Gill RE, Vasil ML (1996) Biochemical and molecular analysis of phospholipase $\mathrm{C}$ and phospholipase $\mathrm{D}$ activity in mycobacteria. Infection and Immunity 64(8): 3259-3266.

52. Le Chevalier F, Cascioferro A, Frigui W, Pawlik A, Boritsch EC, et al (2015) Revisiting the role of phospholipases $C$ in virulence and the lifecycle of Mycobacterium tuberculosis. Sci Rep 5: 16918.

53. Winkler HH, Miller ET (1980) Phospholipase A activity in the hemolysis of sheep and human erythrocytes by Rickettsia prowazeki. Infect Immun 29(2): 316-321.

54.Winkler H(1986) Early events in the interaction of the obligate intracytoplasmic parasite, Rickettsia prowazekii, with eucaryotic cells: entry and lysis. Ann Inst Pasteur Microbiol (1985) pp. 137A(3): 333336.

55. McNamara PJ, Cuevas WA, Songer JG (1995) Toxic phospholipases D of Corynebacterium pseudotuberculosis, C. ulcerans and Arcanobacterium haemolyticum: cloning and sequence homology. Gene 156(1): 113-118.

56. Chen SC, Muller M, Zhou JZ, Wright LC, Sorrell TC (1997) Phospholipase activity in Cryptococcus neoformans: a new virulence factor? J Infect Dis 175(2): 414-420.

57. Schmiel DH, Wagar E, Karamanou L, Weeks D, Miller VL (1998) Phospholipase A of Yersinia enterocolitica contributes to pathogenesis in a mouse model. Infect Immun 66(8): 3941-3951.

58. Brok RG, Boots AP, Dekker N, Verheij HM, Tommassen J (1998) Sequence comparison of outer membrane phospholipases A: implications for structure and for the catalytic mechanism. Res Microbiol 149(10): 703-710.

59. Karlyshev AV, Oyston PC, Williams K, Clark GC, Titball RW, et al (2001) Application of High-Density Array-Based Signature-Tagged Mutagenesis To Discover Novel YersiniaVirulence-Associated Genes. Infect Immun 69(12): 7810-7819.

60. Berstad A, Berstad K, Berstad A(2002) pH-Activated Phospholipase A 2: an Important Mucosal Barrier Breaker in Peptic Ulcer Disease. Scandinavian Journal of gastroenterology 37(6): 738-742.

61. Ziprin RL, Young CR, Byrd JA, Stanker LH, Hume ME, et al. (2001) Role of Campylobacter jejuni potential virulence genes in cecal colonization. Avian Dis 45(3): 549-557.

62. Flieger A, Neumeister B, Cianciotto NP (2002) Characterization of the gene encoding the major secreted lysophospholipase A of Legionella pneumophila and its role in detoxification of lysophosphatidylcholine. Infect Immun 70(11): 6094-6106. 
63. Flieger A, Rydzewski K, Banerji S, Broich M, Heuner K (2004) Cloning and characterization of the gene encoding the major cell-associated phospholipase A of Legionella pneumophila, plaB, exhibiting hemolytic activity. Infect Immun 72(5): 2648-2658.

64. Hiller M, Lang C, Michel W, Flieger A (2017) Secreted phospholipases of the lung pathogen Legionella pneumophila. Int J Med Microbiol pii: S1438-4221(17)30290-4.

65. Istivan TS, Coloe PJ, Fry BN, Ward P, Smith SC(2004) Characterization of a haemolytic phospholipase A2 activity in clinical isolates of Campylobacter concisus. Journal of medical microbiology 53(6): 483493.

66. Bos MP, Tefsen B, Voet P, Weynants V, van Putten JP, et al. (2005) Function of neisserial outer membrane phospholipase $\mathrm{A}$ in autolysis and assessment of its vaccine potential. Infect Immun 73(4): 22222231.

67. Pappa V, Seydel K, Gupta S, Feintuch CM, Potchen MJ, et al. (2015) Lipid metabolites of the phospholipase A 2 pathway and inflammatory cytokines are associated with brain volume in paediatric cerebral malaria. Malar J 14(1): 513

68. Jang KK, Lee ZW, Kim B, Jung YH, Han HJ (2017) Identification and characterization of Vibrio vulnificus plpA encoding a phospholipase A2 essential for pathogenes J Biol Chem 292(41): 17129-17143.
69. Brown SA, Palmer KL, Whiteley M (2008) Revisiting the host as a growth medium. Nat Rev Microbiol 6(9): 657-666.

70. Bernhard W, Hoffmann S, Dombrowsky H, Rau GA, Kamlage A, et al. (2001) Phosphatidylcholine molecular species in lung surfactant: composition in relation to respiratory rate and lung development. Am J Respir Cell Mol Biol 25(6): 725-731.

71. Vance DE (2008) Role of phosphatidylcholine biosynthesis in the regulation of lipoprotein homeostasis. Curr Opin Lipidol 19(3): 229234.

72. Sun Z, Kang Y, Norris MH, Troyer RM, Son MS, et al. (2014) Blocking phosphatidylcholine utilization in Pseudomonas aeruginosa, via mutagenesis of fatty acid, glycerol and choline degradation pathways, confirms the importance of this nutrient source in vivo. PloS one 9(7): e103778.

73. McConnell MJ, Actis L, Pachón J (2013) Acinetobacter baumannii: human infections, factors contributing to pathogenesis and animal FEMS Microbiol Rev 37(2): 130-155.

74. Huang W, Barrett M, Hajicek N, Hicks S, Harden TK, et al. (2013) Small molecule inhibitors of phospholipase $\mathrm{C}$ from a novel high-throughput screen. J Biol Chem 288(8): 5840-5848.

\section{Your next submission with Juniper Publishers will reach you the below assets}

- Quality Editorial service

- Swift Peer Review

- Reprints availability

- E-prints Service

- Manuscript Podcast for convenient understanding

- Global attainment for your research

- Manuscript accessibility in different formats

( Pdf, E-pub, Full Text, Audio)

- Unceasing customer service

Track the below URL for one-step submission https://juniperpublishers.com/online-submission.php 